\title{
MicroRNAs are inappropriate for characterising hearing impairment in mitochondrial disorders
}

\author{
Josef Finsterer $^{1 *}$ and Sinda Zarrouk-Mahjoub ${ }^{2}$
}

Keywords: Mitochondrial, Hereditary neuropathy, Phenotype, Genotype, Multisystem disease, Lactic acidosis

\section{Letter to the Editor}

We read with interest the review by Di Stadio et al. about microRNAs (miRs) for the diagnostic work-up of hypoacusis in MELAS [1]. It was suspected that miR-34a, miR-29b, miR-299-3p, and miR-431 can be useful as biomarkers for detecting and characterising inner ear involvement in MELAS [1]. We have the following comments and concerns.

We do not agree with the statement that "MELAS shows the highest incidence of hearing loss" among mitochondrial disorders [1]. There is another specific mitochondrial syndrome in which per definition every patient presents with hearing impairment, known as maternally inherited diabetes and deafness (MIDD) [2]. Additionally, hypoacusis is frequently found coenzyme-Q deficiency [3, 4].

We also do not agree with the statement that "cochlear conduction cannot be responsible for hearing impairment in MELAS" [1]. Mitochondria are present in nearly all cell types in high amounts, except for erythrocytes. Mitochondrial disorders (MIDs), including MELAS, may even manifest in the bone marrow, presenting as Pearson syndrome or other types of anemia [5] and, additionally, in sensory cells of the cochlea and mucosal cells of which the middle ear is fully lined with.

Hearing impairment in MIDs may not only be due to a peripheral perception or conduction problem but also due to a central conduction or processing defect. The organ most frequently affected in MELAS is the brain (epilepsy, stroke-like episodes, basal ganglia calcification, ataxia, atrophy, confusion, dementia, psychosis, leukoencephalopathy), this is

\footnotetext{
* Correspondence: fifigs1@yahoo.de

${ }^{1}$ Krankenanstalt Rudolfstiftung, Postfach 20, 1180 Vienna, Austria

Full list of author information is available at the end of the article
}

why central causes of hypoacusis should be always considered. Were central causes of hearing impairment excluded in all studies cited in the review article?

miRs are currently pushed and endeavoured as biomarkers or as etiologic or pathogenic factors of various different disorders. However, miR levels are not only abnormal in genetic and inflammatory diseases or ageing but also in malignancies (e.g. prostate cancer), metabolic conditions (e.g. diabetes), or neurodegenerative disorders (e.g. ALS) [6]. For example, miR-29b has been involved in the etiology of prostate cancer [7], miR-34a promotes cell cycle arrest and apoptosis and suppresses cell adhesion in osteosarcoma [8], miR-299-3p has been shown to promote cell growth and to regulate G1/S transition in promyelocytic leukemia [9], and miR-431 is known to regulate axon regeneration in mature sensory neurons [10].

Additionally, miR levels may not only be influenced by various pathologic conditions but also affected by a number of drugs, such as statins [11]. Thus, we should be informed about the current medication of patients discussed in Dr. Di Stadio's review. It is also essential that we know how many of the discussed patients had diabetes, a frequent manifestation of MIDs, including MELAS.

The authors also do not address the effect of heteroplasmy on miR levels and on the variable phenotypes of temporal bones and the cochlea. Also the influence of ageing on the miRs levels was not discussed. We should be informed about the age range of the included patients and if miR levels were dependent on age.

Overall, it remains speculative if miRs influence the phenotype of patients carrying mutations in the mtDNA or whether they reflect disease activity or 
severity, including hearing function in MELAS. Due to their multifactorial involvement, there is currently no evidence for the usefulness of miRs as reliable biomarkers for disease activity, severity, and progression, or whether they have a pathogenic effect in MELAS [12].

\section{Abbreviations}

MELAS: Mitochondrial encephalopathy lactic acidosis and stroke-like episodes; MID: Mitochondrial disorder; MIDD: Maternally inherited diabetes and deafness

\section{Authors' contributions}

Both authors contributed equally, JF: design, literature search, discussion, first draft, SZ-M: literature search, discussion, critical comments. Both authors read and approved the final manuscript.

\section{Ethics approval and consent to participate}

Not relevant

\section{Competing interests}

The authors declare that they have no competing interests.

\section{Publisher's Note}

Springer Nature remains neutral with regard to jurisdictional claims in published maps and institutional affiliations.

\section{Author details}

${ }^{1}$ Krankenanstalt Rudolfstiftung, Postfach 20, 1180 Vienna, Austria. ${ }^{2}$ Pasteur Institute of Tunis, University of Tunis El Manar and Genomics Platform, Tunis, Tunisia.

Received: 6 March 2018 Accepted: 23 May 2018

Published online: 31 May 2018

\section{References}

1. Di Stadio A, Pegoraro V, Giaretta L, Dipietro L, Marozzo R, Angelini C. Hearing impairment in MELAS: new prospective in clinical use of microRNA, a systematic review. Orphanet J Rare Dis 2018;13(1):35. https://doi.org/10. 1186/s13023-018-0770-1.

2. Naing A, Kenchaiah M, Krishnan B, Mir F, Charnley A, Egan C, Bano G. Maternally inherited diabetes and deafness (MIDD): diagnosis and management. J Diabetes Complicat. 2014:28:542-6.

3. Park E, Ahn YH, Kang HG, Yoo KH, Won NH, Lee KB, Moon KC, Seong MW, Gwon TR, Park SS, Cheong HI. COQ6 mutations in children with steroidresistant focal segmental glomerulosclerosis and sensorineural hearing loss. Am J Kidney Dis. 2017;70(1):139-44.

4. Heeringa SF, Chernin G, Chaki M, Zhou W, Sloan AJ, Ji Z, Xie LX, Salviati L, Hurd TW, Vega-Warner V, Killen PD, Raphael Y, Ashraf S, Ovunc B, Schoeb DS, McLaughlin HM, Airik R, Vlangos CN, Gbadegesin R, Hinkes B, Saisawat P, Trevisson E, Doimo M, Casarin A, Pertegato V, Giorgi G, Prokisch H, Rötig A, Nürnberg G, Becker C, Wang S, Ozaltin F, Topaloglu R, Bakkaloglu A, Bakkaloglu SA, Müller D, Beissert A, Mir S, Berdeli A, Varpizen S, Zenker M, Matejas V, Santos-Ocaña C, Navas P, Kusakabe T, Kispert A, Akman S, Soliman NA, Krick S, Mundel P, Reiser J, Nürnberg P, Clarke CF, Wiggins RC, Faul C, Hildebrandt F. COQ6 mutations in human patients produce nephrotic syndrome with sensorineural deafness. J Clin Invest. 2011; 121(5):2013-24.

5. Finsterer J, Frank M. Haematological abnormalities in mitochondrial disorders. Singap Med J. 2015;56:412-9.

6. Si Y, Cui X, Crossman DK, Hao J, Kazamel M, Kwon Y, King PH. Muscle microRNA signatures as biomarkers of disease progression in amyotrophic lateral sclerosis. Neurobiol Dis. 2018; https://doi.org/10. 1016/j.nbd.2018.02.009.

7. Ivanovic RF, Viana NI, Morais DR, Silva IA, Leite KR, Pontes-Junior J, Inoue G, Nahas WC, Srougi M, Reis ST. miR-29b enhances prostate cancer cell invasion independently of MMP-2 expression. Cancer Cell Int. 2018;18(18) https://doi.org/10.1186/s12935-018-0516-0. eCollection 2018
8. Gang L, Qun L, Liu WD, Li YS, Xu YZ, Yuan DT. MicroRNA-34a promotes cell cycle arrest and apoptosis and suppresses cell adhesion by targeting DUSP1 in osteosarcoma. Am J Transl Res. 2017;9:5388-99.

9. Wu SQ, Zhang LH, Huang HB, Li YP, Niu WY, Zhan R. miR-299-5p promotes cell growth and regulates G1/S transition by targeting p21Cip1/Waf1 in acute promyelocytic leukemia. Oncol Lett. 2016;12:741-7.

10. Wu D, Murashov AK. MicroRNA-431 regulates axon regeneration in mature sensory neurons by targeting the Wnt antagonist Kremen1. Front Mol Neurosci. 2013;6:35. https://doi.org/10.3389/fnmol.2013.00035.

11. Zambrano T, Hirata RDC, Hirata MH, Cerda Á, Salazar LA. Statins differentially modulate microRNAs expression in peripheral cells of hyperlipidemic subjects: a pilot study. Eur J Pharm Sci. 2018;117:55-61.

12. Finsterer J, Zarrouk-Mahjoub S. Biomarkers for detecting mitochondrial disorders. J Clin Med. 2018;7(2) https://doi.org/10.3390/jcm7020016.

\section{Ready to submit your research? Choose BMC and benefit from:}

- fast, convenient online submission

- thorough peer review by experienced researchers in your field

- rapid publication on acceptance

- support for research data, including large and complex data types

- gold Open Access which fosters wider collaboration and increased citations

- maximum visibility for your research: over $100 \mathrm{M}$ website views per year

At BMC, research is always in progress.

Learn more biomedcentral.com/submissions 